Research paper

\title{
Direct synthesis of mesoporous aluminosilicates from Indonesian kaolin clay without calcination
}

\author{
Imroatul Qoniah $^{\mathrm{a}, \mathrm{b}}$, Didik Prasetyoko ${ }^{\mathrm{b}, *}$, Hasliza Bahruji $^{\mathrm{c}}$, Sugeng Triwahyono ${ }^{\mathrm{d}}$, Aishah Abdul Jalil ${ }^{\mathrm{d}}$, \\ Suprapto ${ }^{\mathrm{b}}$, Hartati ${ }^{\mathrm{e}}$, Tri Esti Purbaningtias ${ }^{\mathrm{f}}$ \\ a Department of Environmental Engineering, Islamic University of Jl. Kaliurang Km. 14.5, Sleman 55584, Yogyakarta, Indonesia \\ b Department of Chemistry, Faculty of Mathematics and Natural Sciences, Institut Teknologi Sepuluh Nopember, Keputih, Sukolilo, Surabaya 60111, Indonesia \\ c Cardiff Catalysis Institute, Cardiff University, CF10 3AT Cardiff, United Kingdom \\ d Ibnu Sina Institute for Fundamental Science Studies, Universiti Teknologi Malaysia, Skudai, Johor Bahru 81310, Malaysia \\ e Department of Chemistry, Faculty of Science and Technology, Universitas Airlangga, Surabaya 60115, Indonesia \\ ${ }^{\mathrm{f}}$ Diploma of Analytical Chemistry, Islamic University of Jl. Kaliurang Km. 14.5, Sleman 55584, Yogyakarta, Indonesia
}

\section{A R T I C L E I N F O}

\section{Article history:}

Received 30 March 2015

Received in revised form 25 September 2015

Accepted 7 October 2015

Available online 23 October 2015

Keywords:

Kaolin

Mesoporous

Aluminosilicates based-materials

Surface acidity

\begin{abstract}
A B S T R A C T
The transformation of kaolin to amorphous mesoporous aluminosilicate was investigated in this study. We demonstrated the use of koalin as silica and alumina sources without prior pretreatment. Two steps synthesis method were carried out; hydrothermal reaction at $80^{\circ} \mathrm{C}$, followed by addition of mesoporogen cetyltrimethylammonium bromide (CTABr) surfactant. We observed that prolonging the synthesis period improves the surface area of the aluminosilicate with enhances mesopore volume and surface acidity.
\end{abstract}

(C) 2015 Elsevier B.V. All rights reserved.

\section{Introduction}

There is a growing challenge for developing robust materials based on aluminosilicate framework mainly to be used as catalyst for the synthesis of fine chemicals. Considerable effort has been dedicated to achieve desired mesoporous aluminosilicate materials with high surface area and hydrothermal stability as acid catalyst. Mesoporous structure in aluminosilicate is beneficial in catalytic application; the unique mesopores improve the mass transport and the diffusion of chemical reactant that subsequently accelerates the catalytic process (PérezRamírez et al., 2008). Mass transport is faster in the catalyst cavity that offers shorter diffusion pathway between the reactant and the active site of the catalyst (Na et al., 2013).

Although the synthesis of aluminosilicates are well-established, commercial silica and alumina for example tetraethylorthosilicate ( $\mathrm{Li}$ et al., 2013; Enterría et al., 2014; Li et al., 2010), colloidal silica (Xue et al., 2012), aluminum isopropoxide (Rownaghi et al., 2012; Jian et al., 2013), aluminum nitrate nonahydrate (Gonçalves et al., 2008) and sodium aluminate (Petushkov et al., 2011; Liu et al., 2014) are often used as starting material. Natural minerals provides alternative green and sustainable silica and alumina sources to replace the used of

\footnotetext{
* Corresponding author.

E-mail addresses: didikp@chem.its.ac.id, didik.prasetyoko@gmail.com (D. Prasetyoko).
}

synthetic chemicals. Many researchers have explored the potential of silica from rice husk ash (Prasetyoko et al., 2012), palygorskite (Jiang et al., 2014), and kaolin (Pan et al., 2013) for aluminosilicate synthesis. However, these materials must undergo calcination and acid leaching pretreatment to eliminate impurities that have significant influences on the physical properties of the synthesized materials. Kaolin is a clay mineral with the chemical composition of $\mathrm{Al}_{2} \mathrm{Si}_{2} \mathrm{O}_{5}(\mathrm{OH})_{4}$. It consists of high $\mathrm{Si}$ and $\mathrm{Al}$ contents that is beneficial for aluminosilicate synthesis. The $\mathrm{Si}$ and $\mathrm{Al}$ in kaolin however exist in inactive states, which make the transformation into aluminosilicate is a challenging process (Chandrasekhar and Pramada, 2008). Conversion of kaolin into silicabased materials such as Ln-ZSM-5/MCM-41 (Li et al., 2010), mesoporous $\mathrm{Al}_{2} \mathrm{O}_{3}$ (Liu and Yang, 2010; Pan et al., 2013), Al-MCM-41 (Du and Yang, 2012) requires calcination at high temperature to activate the kaolin. Soft-template such as surfactant is added into the gel mixture or after crystallization period, which control the pore structure and the particle size of the intercrystalline powder (Li et al., 2013; Enterría et al., 2014).

Here, we report direct synthesis of amorphous mesoporous aluminosilicate using raw kaolin clay as the $\mathrm{Si}$ and $\mathrm{Al}$ sources without prior pre-treatment. Silicalite-1 seed was used as structure-directing agent (SDA) to obtain MFI-type framework, while cationic surfactant, CTABr was used as mesoporogen. We studied the transformation of kaolin into mesoporous aluminosilicate by monitoring the changes in porosity, 